\title{
Effect of human lymphoblastoid interferon on insulin synthesis and secretion in isolated human pancreatic islets
}

\author{
C.J. Rhodes and K. W. Taylor \\ Department of Biochemistry, The London Hospital Medical College, London, UK
}

Summary. Human islets of Langerhans were isolated from the pancreas removed from a 13-year-old female transplant donor. The islets were incubated in a culture medium for $24 \mathrm{~h}$ in the presence of human lymphoblastoid interferon (1000 units $/ \mathrm{ml}$ ). Insulin secretion, proinsulin biosynthesis, total protein biosynthesis and total insulin content were assessed at various concentrations of glucose in the presence of interferon. In interferon-treated islets glucose-stimulated insu- lin secretion was unaltered from that of control islets; however, glucose-stimulated proinsulin biosynthesis was specifically inhibited by interferon $(48 \%, p<0.025)$. Total protein biosynthesis and total insulin content were not significantly affected by interferon.

Key words: Interferon, insulin biosynthesis, insulin secretion, human pancreatic islets.
Interferon is able to protect most types of mammalian cells from a viral infection by modifying the protein synthesizing system of the host cell $[1,2]$. At low concentrations, $(<50$ units $/ \mathrm{ml})$, interferon preferentially inhibits viral replication, leaving host cell protein synthesis untouched [1]. However, at higher concentrations ( $>150$ units $/ \mathrm{ml}$ ), interferon also may reduce host cell protein synthesis [3], and inhibit the synthesis of certain inducible proteins $[4,5]$.

A number of viruses are known to induce diabetes in experimental animals by direct effects on the islets of Langerhans [6]. Viruses also can induce the production of interferon in some cells [1]. While interferons under some circumstances can protect against subsequent inoculation of such diabetogenic viruses $[7,8]$, it is not known whether high local concentrations of interferon may have other effects on $\beta$-cell function. With this in mind, we have investigated the effect of a high concentration of interferon on human pancreatic islet $\beta$-cell function.

\section{Materials and methods}

\section{Human islet isolation}

Part of the tail of the pancreas from a renal transplant donor was removed surgically in a minimum ischaemic period and placed in icecold sterile RPMI 1640 tissue culture medium containing glucose $(5 \mathrm{mmol} / 1), 10 \%$ fetal calf serum, penicillin $(100 \mathrm{U} / \mathrm{ml})$ and strepto- mycin $(0.1 \mathrm{mg} / \mathrm{ml})$, for carriage back to the laboratory. Removal of the pancreas was conducted under the guidelines of The London Hospital Ethical Committee. The patient was a 13-year-old female with a brain tumour. There was no previous history of diabetes or other metabolic disorder. The pancreas was washed in sterile bicarbonate buffered medium gassed with $\mathrm{O}_{2}+\mathrm{CO}_{2}(95 \%: 5 \%)$ immediately before use [9] and then cut into pieces of approximately $1 \mathrm{~g}$ weight. These pieces were distended by injection with bicarbonate buffered medium (pH 7.4), containing collagenase ( $1 \mathrm{mg} / \mathrm{ml}$ ) (Type I, Sigma (London), Poole, Dorset, UK), chopped into small pieces $\left(2-3 \mathrm{~mm}^{3}\right)$, centrifuged $(2,500 \mathrm{rev} / \mathrm{min}$ for $20 \mathrm{~s})$ and the collagenase solution decanted. The pancreas pieces were then suspended in fresh bicarbonate buffer $(10 \mathrm{ml})[9]$, containing collagenase $(3 \mathrm{mg} / \mathrm{ml})$ and shaken for $30 \mathrm{~min}$ at $37^{\circ} \mathrm{C}$, using a mechanical flask shaker (Griffin, London, UK). From the resultant digest, islets were harvested as described by Howell and Taylor [10], using a drawn out Pasteur pipette under aseptic conditions and viewing under a dissection microscope. From approximately $5 \mathrm{~g}$ of pancreas 543 islets were obtained.

\section{Islet treatment and assay of islet $\beta$-cell function}

Harvested islets were placed in groups of $100 / \mathrm{ml}$ in RPMI 1640 tissue culture medium containing glucose $(2 \mathrm{mmol} / \mathrm{l}), 10 \%$ fetal calf serum, penicilin $(100 \mathrm{U} / \mathrm{ml})$ and streptomycin $(0.1 \mathrm{mg} / \mathrm{ml})$. The islets were incubated for $24 \mathrm{~h}$ either with or without addition of human lymphoblastoid interferon (1000 units $/ \mathrm{ml}$, Burroughs Wellcome, Beckenham, Kent, UK), in a $\mathrm{CO}_{2}$ incubator (LEEC, Leicester, UK) at $37^{\circ} \mathrm{C}$. After washing in bicarbonate buffer [9], islets were placed in groups of $10-15$ in microcentrifuge tubes. Each group was incubated in bicarbonate buffer $(150 \mu \mathrm{l})$ with glucose $(2$ or $20 \mathrm{mmol} / \mathrm{l})$ and L-phenyl[2,3- $\left.{ }^{3} \mathrm{H}\right]$-alanine $(80 \mu \mathrm{Ci} / \mathrm{ml}$ ) (Amersham International, Amersham, Bucks, UK) for $90 \mathrm{~min}$ at $37^{\circ} \mathrm{C}$ in a shaking water bath. After centrifugation $(2,500 \mathrm{rev} / \mathrm{min}$ for $20 \mathrm{~s})$, the supernatant was removed for radioimmunoassay of insulin secreted [11]. (Human insulin stan- 
Table 1. Effects of human leucocyte interferon on various parameters of isolated human islet function at basal and raised glucose concentrations

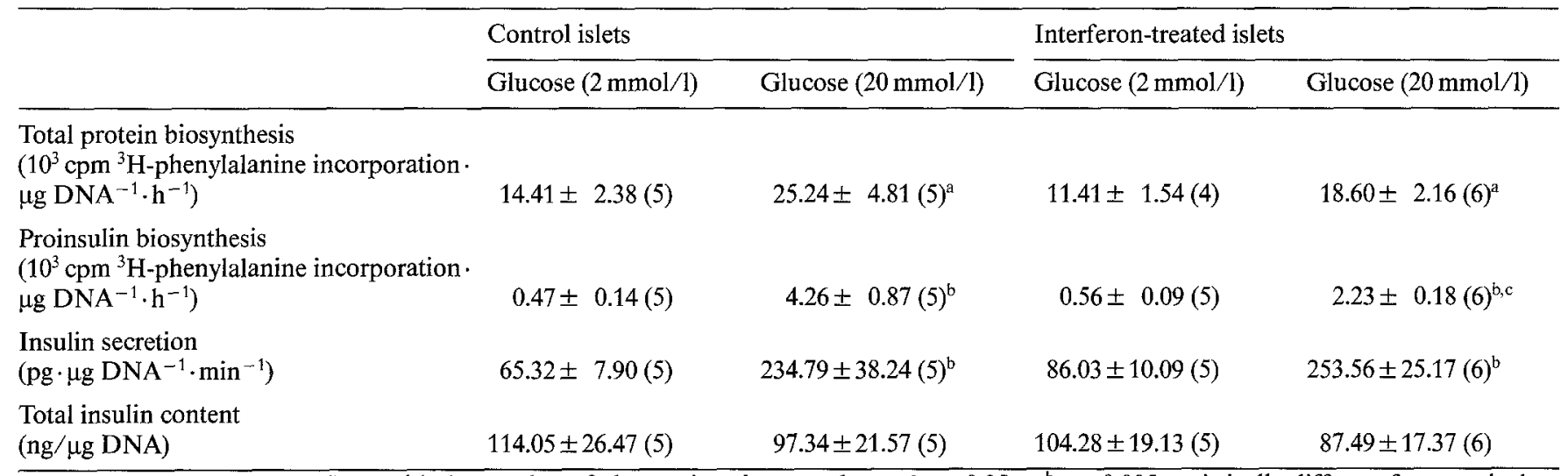

Results are given as mean \pm SEM with the number of observations in parentheses. ${ }^{\mathrm{a}} p<0.05$ or ${ }^{\mathrm{b}} p<0.005$ statistically different from equivalent $2 \mathrm{mmol} / 1$ glucose-treated islets ${ }^{c} p<0.025$ statistically different from equivalent control islets.

dard and binding reagent were from Wellcome Research Reagents, Beckenham, Kent, UK). The islets were then washed in phosphate buffered saline (PBS, $1 \mathrm{ml})$, containing phenylalanine $(10 \mathrm{mmol} / \mathrm{l})$ and resuspended in $100 \mu \mathrm{ml}$ PBS and sonicated ( 25 watts for $15 \mathrm{~s}$, Branson - B15P, Dawe Instruments, London, UK). The resulting sonicate was assayed for islet total insulin [11] and DNA content [12]. Incorporation of labelled phenylalanine into total protein and immuno-extractable proinsulin was assessed by the method of Berne [13]. In these experiments, no attempt was made to distinguish between proinsulin and insulin.

\section{Statistical analysis}

Results are expressed as mean $\pm S E M$, with the number of observations in parentheses. Significant differences between results were assessed by Student's t-test. Values with $p<0.05$ were regarded as significant.

\section{Results}

The rates of proinsulin biosynthesis and insulin secretion at glucose $(20 \mathrm{mmol} / \mathrm{l})$ were specifically increased in control isolated human islets when compared with the rate at glucose $(2 \mathrm{mmol} / \mathrm{l})$ (Table 1$)$. The rate of total protein biosynthesis was similarly raised, but to a much lesser extent. Total insulin content of control islets was not significantly affected by altering glucose concentrations.

In islets treated with interferon (1000 units $/ \mathrm{ml})$, insulin secretion and total insulin content were unaltered, giving results similar to those obtained in control islets incubated with glucose ( 2 and $20 \mathrm{mmol} / 1$ ). By contrast, interferon specifically and significantly inhibited $20 \mathrm{mmol} / 1$ glucose-induced proinsulin biosynthesis $(p<0.025)$. There was a slight reduction in total protein biosynthesis with glucose ( 2 and $20 \mathrm{mmol} / \mathrm{l})$ in interferon-treated islets; however, this was not statistically significant.

The DNA content of the islets $(0.137 \pm$ $0.007 \mu \mathrm{g} /$ islet) did not vary significantly between groups of islets and was comparable to that of other human islet studies.

\section{Discussion}

That high glucose concentration induces an increase in insulin secretion and proinsulin biosynthesis in isolated human islets has been reported elsewhere [14-16]. Total protein biosynthesis (to a lesser extent) is also significantly raised by high glucose concentrations, and this may be a reflection of increased glucose utilisation [14], as well as increased proinsulin biosynthesis.

In this study, a high level of human lymphoblastoid interferon ( 1000 units $/ \mathrm{ml})$ inhibits glucose-induced proinsulin biosynthesis in isolated human pancreatic islets. Similar observations for interferon inhibition of the synthesis of inducible proteins have been made in other systems $[4,5,17]$. At this high interferon concentration, total protein biosynthesis may also be reduced [3].

Interferon is thought to inhibit protein biosynthesis by inducing at least two enzyme systems via specific receptors on the host cell $[1,2]$. One of the enzymes induced by interferon, $2^{\prime}-5^{\prime}$ oligoadenylate synthetase, synthesises certain oligoadenylates from ATP. These oligoadenylates activate latent endoribonucleases which cleave free single-stranded RNA (including free cytoplasmic $\mathrm{mRNA}$ ), resulting in a decrease in new protein synthesis in the host cell. The other interferon-induced enzyme is a protein kinase, which phosphorylates an initiation factor involved in the initiation of protein synthesis, known as eIF2. Once phosphorylated, eIF2 activity is inhibited, hence the initiation of new protein biosynthesis in the cell is reduced. We suggest that interferon is inducing these enzyme systems in the isolated human islet $\beta$ cells, which in turn inhibits glucose-induced proinsulin biosynthesis.

It is uncertain whether the effect of high concentrations of interferon are important in virus-induced diabetes, in which under some circumstances proinsulin biosynthesis may be decreased [18]. With regard to this, a high local concentration of interferon in the vicinity of the islet $\beta$ cells might temporarily diminish proinsulin biosynthesis. 
Acknowledgements. We wish to thank Mr. O.N.Fernando for access to clinical material, Mr. T. Ward for technical assistance and Burroughs Wellcome Ltd. for the gift of human lymphoblastoid interferon. The financial support of the Medical Research Council and British Diabetic Association is gratefully acknowledged.

\section{References}

1. Lengyel P (1982) Biochemistry of interferons and their actions. Ann Rev Biochem 51: 251-282

2. Kerr IM, Wreschner DH, Silverman RH, Cayley PJ, Knight M (1981) The 2-5A (ppp A2'p5 $5^{\prime} 2^{\prime} \mathrm{p}^{\prime} \mathrm{A}$ ) and protein kinase systems in interferon-treated and control cells. Adv Cyclic Nucleotide Res 14: $469-478$

3. Falcoff R, Scheps R, Sanceau J,Catinot L, Falcoff E (1975) Protein synthesis in interferon treated cells. Biochimie 57: 1109-1111

4. Beck G, Poindron P, Illinger D, Beck JP, Ebel J-P, Falcoff R (1974) Inhibition of steroid inducible tyrosine aminotransferase by mouse and rat interferon in hepatoma tissue culture cells. FEBS Lett 48: 297-300

5. Rossi GB, Dolei A, Goe L, Benedetto A, Matarese P, Bellardelli F (1977) Inhibition of transcription and translation of globin messenger RNA in dimethyl sulfoxide-stimulated Friend erythroleukemic cells treated with interferon. Proc Natl Acad Sci USA 74: 2036-2040

6. Notkins AL, Yoon JW, Onodera T, Toniolo A, Bennett-Jenson A (1981) Virus induced diabetes mellitus. In: Pollard M (ed) Perspectives in virology, Vol XI. Allen R Liss, New York, pp 141-162

7. Yoon JW, Cha C-Y, Jordan GN (1983) The role of interferon in virus induced diabetes. J Infect Dis 147: 155-159

8. Wilson GL, Bellamo SC, Craighead JE (1983) Effect of interferon on encephalomyocarditis virus infection on cultured mouse pancreatic B cells. Diabetologia 24: 38-41

9. Gey GO, Gey MK (1936) Maintenance of human normal cells and tumour cells in tissue culture. Am J Cancer 27: 45-76
10. Howell SL, Taylor KW (1968) Potassium ions and the secretion of insulin by islets of Langerhans incubated in vitro. Biochem J 108: $17-24$

11. Hales CN, Randle PJ (1963) Immunoassay of insulin with insulin antibody precipitate. Biochem J 88: 137-146

12. Vytàsék R (1982) A sensitive fluorometric assay for the determination of DNA. Anal Biochem 120:243-248

13. Berne C (1975) Anti-insulin serum coupled to Sepharose 4B as a tool for the investigation of insulin biosynthesis in the B-cells of obese hyperglycemic mice. Endocrinology 97:1241-1247

14. Ashcroft SJH, Basset JM, Randle PJ (1971) Isolation of human pancreatic islets capable of releasing insulin and metabolising glucose in vitro. Lancet $1: 888-889$

15. Lohmann D, Jahr H, Verlohren H-J, Schmidt S, Heilmann W, Zülke H, Hartig W, Mättig W (1980) Insulin secretion in maturity onset diabetes function of isolated islets. Horm Metab Res 12: 349-353

16. Grant AM, Christie MR, Ashcroft SJH (1980) Insulin release from human pancreatic islets in vitro. Diabetologia $25: 114-117$

17. Rhodes CJ, Taylor KW (1984) The effect of mouse fibroblast interferon on proinsulin biosynthesis. Biochem Soc Trans 12: 262

18. Hellqvist LNB, Taylor KW, Zaluzny S (1981) Selective disorganisation of biochemical function in B-cells of islets of Langerhans infected by EMC-M virus in tissue culture. FEBS Lett 132: $215-218$

Received: 11 June 1984

and in revised form: 17 September 1984

Professor K. W. Taylor

Department of Biochemistry

The London Hospital Medical College

Turner Street

London E1 2AD

UK 